Article

\title{
Swimming Abilities of Temperate Pelagic Fish Larvae Prove that They May Control Their Dispersion in Coastal Areas
}

\author{
Vânia Baptista ${ }^{1, *(\mathbb{D}}$, Pedro Morais ${ }^{1}{ }^{(\mathbb{D}}$, Joana Cruz ${ }^{1}$, Sara Castanho ${ }^{2}{ }^{(}$, Laura Ribeiro ${ }^{2}$, \\ Pedro Pousão-Ferreira ${ }^{2}$, Francisco Leitão ${ }^{1,3}{ }^{\mathbb{D}}$, Eric Wolanski ${ }^{4}$ and \\ Maria Alexandra Teodósio 1,3 \\ 1 CCMAR - Centre of Marine Sciences, University of Algarve, Campus de Gambelas, 8005-139 Faro, Portugal; \\ pmorais@ualg.pt (P.M.); jmcruz@ualg.pt (J.C.); fleitao@ualg.pt (F.L.); mchichar@ualg.pt (M.A.T.) \\ 2 IPMA-Portuguese Institute for the Sea and Atmosphere/EPPO-Aquaculture Research Station, \\ Av. 5 de Outubro, 8700-305 Olhão, Portugal; scastanho@ipma.pt (S.C.); lribeiro@ipma.pt (L.R.); \\ pedro.pousao@ipma.pt (P.P.-F.) \\ 3 University of Algarve, Campus de Gambelas, 8005-139 Faro, Portugal \\ 4 TropWATER and College of Marine \& Environmental Sciences, James Cook University, \\ Townsville, QLD 4811, Australia; eric.wolanski@jcu.edu.au \\ * Correspondence: vcbaptista@ualg.pt
}

Received: 29 May 2019; Accepted: 28 September 2019; Published: 1 October 2019

check for updates

\begin{abstract}
The Sense Acuity and Behavioral (SAAB) Hypothesis proposes that the swimming capabilities and sensorial acuity of temperate fish larvae allows them to find and swim towards coastal nursery areas, which are crucial for their recruitment. To gather further evidence to support this theory, it is necessary to understand how horizontal swimming capability varies along fish larvae ontogeny. Therefore, we studied the swimming capability of white seabream Diplodus sargus (Linnaeus, 1758) larvae along ontogeny, and their relationship with physiological condition. Thus, critical swimming speed $\left(\mathrm{U}_{\text {crit }}\right)$ and the distance swam $(\mathrm{km})$ during endurance tests were determined for fish larvae from 15 to 55 days post-hatching (DPH), and their physiological condition (RNA, DNA and protein contents) was assessed. The critical swimming speed of white seabream larvae increased along ontogeny from $1.1 \mathrm{~cm} \mathrm{~s}^{-1}(15 \mathrm{DPH})$ to $23 \mathrm{~cm} \mathrm{~s}^{-1}$ (50 and $\left.55 \mathrm{DPH}\right)$, and the distance swam by larvae in the endurance experiments increased from $0.01 \mathrm{~km}(15 \mathrm{DPH})$ to $86.5 \mathrm{~km}(45 \mathrm{DPH})$. This finding supports one of the premises of the SAAB hypothesis, which proposes that fish larvae can influence their transport and distribution in coastal areas due to their swimming capabilities. The relationship between larvae's physiological condition and swimming capabilities were not evident in this study. Overall, this study provides critical information for understanding the link between population dynamics and connectivity with the management and conservation of fish stocks.
\end{abstract}

Keywords: fish larvae; recruitment; dispersion; swimming capacity; $\mathrm{U}_{\text {crit }}$; endurance

\section{Introduction}

The pelagic eggs and larvae of temperate marine fish species may remain in the pelagic environment for weeks or months before being recruited into nursery habitats [1,2]. Passive transport of eggs and pre-metamorphic larvae is dictated by currents, tides, and weather events [3], which may either transport them towards coastal nursery areas (i.e., coastal lagoons, estuaries, rocky shore habitats) or away from them [2]. This passive stage is greatly influenced by biological (e.g., starvation and predation) and physical processes related to larval transport and retention $[4,5]$. 
Recently, the Sense Acuity And Behavioral (SAAB) hypothesis propose that recruitment into nursery areas is maximized due to larvae's sense acuity and behavioral responses to nursery cues associated with coastal areas (e.g., odor, sound, and visual cues) [2]. The hierarchy of the sensorial cues used to detect and navigate towards nursery areas change not only throughout ontogeny but also and according to the distance from the nursery cues [2]. Thus, post-flexion fish larvae use sun-compass orientation, the Earth's geomagnetic field, and innate behaviors to navigate towards the coastal nurseries when they are away from them $[3,6,7]$. However, when post-flexion larvae are in the range of nursery cues, they orientate their swimming to follow odor, sound, and visual cues (see Figure 2 in [2]). Thus, the development of swimming capabilities and behaviors that interact with physical transport processes influences larval dispersion outcomes [6,8-11], settlement location [12], and recruitment success [13].

A few post-flexion fish larvae species are exceptional swimmers, capable of significant horizontal and vertical displacement $[11,14]$. Some fish larvae can swim at speeds higher than coastal currents, in a highly directional way and for long distances $[14,15]$. Fish larvae can also adjust their vertical position [10] to enter currents that facilitate their transport, and in search of a nursery habitat [16]. These swimming capabilities also impact other ecological processes, such as the response of larvae to predators, foraging abilities $[4,17,18]$, interaction with conspecifics, and the biotic and abiotic conditions larvae may experience [19]. Ultimately, understanding the mechanisms that influence larval dispersal and fish population dynamics is essential to the management of marine fish populations [20].

Most swimming performance studies have focused on tropical coral reef fish larvae [14,21-25], while those focusing on temperate species have only increased in recent years [19,26-31]. Comparatively to fish larvae of tropical species, temperate fish larvae are considered to be weak swimmers, swimming at slower speeds than tropical species $[23,28,32]$. Therefore, it has become clear that there is still a deficit in our understanding of how fish larvae's biological traits and ontogeny development, in particular, interact with the physiological condition of fish larvae and their capacity to follow nursery cues, all of which may contribute to our knowledge of fish recruitment fluctuations.

Therefore, and as part of a broader research effort, we aim to determine how the swimming capacity of laboratory-reared temperate fish larvae vary along ontogeny and how their physiological condition influences their ability to follow coastal nursery habitat cues. The white seabream Diplodus sargus (Linnaeus 1758) (Pisces: Sparidae) was our model species, and we conducted laboratory experiments measuring the critical swimming speed $\left(\mathrm{U}_{\text {crit }}\right)$, and maximum distance swam (swimming endurance) throughout ontogeny, from 15 to 55 days post-hatching. The effect of their physiological condition (nucleic acids and proteins quantification) on swimming capacity was also evaluated. Our general hypothesis is that post-flexion fish larvae in good physiological condition will display improved swimming performance [33], which would ultimately lead to higher recruitment [13], in comparison to early-stage larvae and those in poor physiological condition. Our experimental design consisted of assessing the locomotory behavioral and inferring the critical swimming speed and endurance of white seabream larvae along ontogeny, combined with analysis of their physiological condition.

\section{Material and Methods}

\subsection{Model Species}

The Diplodus genus sustains important commercial and recreational fisheries along the Portuguese coast, as the white seabream Diplodus sargus (Linnaeus 1758) (Pisces: Sparidae) [34,35]. The white seabream is a demersal fish present along the continental shelf of the northeastern Atlantic and the Mediterranean Sea [36], as well as coastal lagoons [37], and estuaries [38]. This species is generally more abundant from shore to $50 \mathrm{~m}$ depth [39], inhabiting coastal rocky reefs, sandy bottoms, and seagrass beds [36]. The adults spawn from March to June in coastal areas [38], producing pelagic eggs that hatch after three days, while larvae may spend up to 3-4 weeks in the pelagic environment [40] before reaching recruitment habitats such as sandy-rocky bottoms [39], coastal lagoons [41] and estuaries [38]. 
Juveniles remain in these habitats for approximately one year [42] before heading towards deeper habitats to recruit into the adult population [39].

\subsection{Overview of the Experimental Design}

The white seabream larvae used in this study were obtained from natural spawns of wild brood stocks held at the Aquaculture Research Station (EPPO) of the Portuguese Institute for the Ocean and Atmosphere (IPMA) in Olhão (Portugal). Experiments were conducted in a quiet temperature-controlled room during 2016. Exogenous feeding started at three days post-hatching (DPH) to match with the opening of the larvae's mouths [43]. Larvae were fed ad libitum with rotifers Brachionus sp. (Pallas, 1766) for the first $14 \mathrm{DPH}$; with rotifers, branchiops Artemia spp. (Leach, 1819) nauplii, and dry feed (Caviar from BernAqua) from 15 to 21 days post-hatching (DPH); and with a dry feed of increasing granulometry as development progressed.

The swimming capacity and behavior of white seabream larvae were tested and evaluated with three types of experiments. The critical swimming speed $\left(\mathrm{U}_{\text {crit }}\right)$ and swimming endurance experiments were performed in nine occasions along ontogeny (pre-flexion: $15 \mathrm{DPH}$; flexion: $20 \mathrm{DPH}$, post-flexion: $25,30,35,40,45,50$, and $55 \mathrm{DPH}$ ) (Table 1). These larvae were reared at $18.8 \pm 0.5^{\circ} \mathrm{C}$ during the $\mathrm{U}_{\text {crit }}$ experiments (March-April 2016) and at $20.9 \pm 1.3^{\circ} \mathrm{C}$ during the swimming endurance trials (May-July 2016). Locomotory behavior observations were done to evaluate the type of swimming larvae display in a stationary environment.

After each test, larvae were frozen in liquid nitrogen and then stored at $-80^{\circ} \mathrm{C}$ for subsequent biochemical analysis (nucleic acids and protein analysis). The total length (TL; $\pm 0.01 \mathrm{~mm}$ ) of larvae was assessed based on photographs of larvae taken before biochemical analysis under a stereoscope (Leica 58APO - Leica Microsystems GmbH Wetzlar Germany, coupled with a Leica MC170 HC camera - Leica Microsystems GmbH Wetzlar Germany) and using Image J (version 1.50i). Then, larvae were freeze-dried and weighed ( $\pm 1 \mu \mathrm{g}$ dry weight $-\mathrm{DW})$ on an electronic microbalance (Sartorius M5P).

Table 1. Number of white seabream Diplodus sargus (Linnaeus, 1758) larvae used in the critical swimming speed ( $\mathrm{U}_{\text {Crit }}$ ), endurance (water flow speed is in italics), and Modal Action Patterns (MAPs) experiments at nine occasions along ontogeny-15, 20, 25, 30, 35, 40, 45, 50, and 55 days post-hatching $(\mathrm{DPH})$

\begin{tabular}{cccccccccc}
\hline \multirow{2}{*}{ Experiment } & $\mathbf{1 5}$ & $\mathbf{2 0}$ & $\mathbf{2 5}$ & $\mathbf{3 0}$ & $\mathbf{3 5}$ & $\mathbf{4 0}$ & $\mathbf{4 5}$ & $\mathbf{5 0}$ & $\mathbf{5 5}$ \\
& $\mathbf{D P H}$ & $\mathbf{D P H}$ & $\mathbf{D P H}$ & $\mathbf{D P H}$ & $\mathbf{D P H}$ & $\mathbf{D P H}$ & $\mathbf{D P H}$ & $\mathbf{D P H}$ & $\mathbf{D P H}$ \\
\hline $\mathbf{U}_{\text {Crit }}$ & 15 & 16 & 16 & 16 & 16 & 16 & 16 & 16 & 16 \\
\hline Endurance & 8 & - & 8 & - & 8 & - & 8 & - & - \\
\hline flow speed $\left(\mathrm{cm} \mathrm{s}^{-1}\right)$ & 1.5 & & 5.0 & - & 6.0 & -10.0 & & 10 \\
\hline MAPs & 10 & 10 & 10 & 10 & 10 & 10 & 10 & 10 & 10 \\
\hline
\end{tabular}

\subsubsection{Critical Swimming Speed ( $\left.\mathrm{U}_{\text {crit }}\right)$}

The critical swimming speed $\left(\mathrm{U}_{\text {crit }}, \mathrm{cm} \mathrm{s}^{-1}\right)$ of white seabream larvae was inferred in a multilane swimming chamber, following the design of Stobutzki and Bellwood [14,21] and later adapted by Faria et al. [44]. The chamber was made of transparent Perspex ${ }^{\circledR}$ comprising six parallel swimming lanes (30 mm wide, $50 \mathrm{~mm}$ high, $180 \mathrm{~mm}$ long) (Figure 1). Plastic flow diffusers ( $\emptyset-5 \mathrm{~mm} ; 40 \mathrm{~mm}$ long) were placed after the intake water valve to uniformize flow in the different lanes. Two mesh bands were installed on both ends of each lane of the chamber to retain larvae within the chamber. Details on the swimming chamber apparatus were described by Faria et al. [44]. 


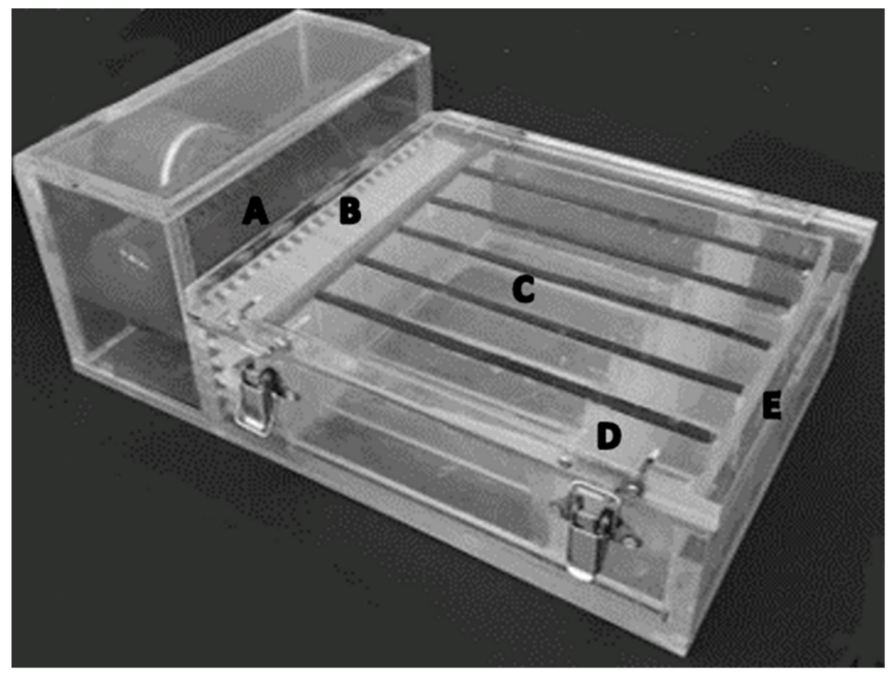

Figure 1. Swimming chamber used in the critical swimming speed and swimming endurance experiments carried out with white seabream Diplodus sargus (Linnaeus, 1758) larvae. The design of this swimming chamber was based on Stobutzki and Bellwood [14,21] and later modified by Faria et al. [44]. Water flows into the swimming chamber through a perforated PVC pipe (A), which then passes through two sets of plastic flow diffusers ( $\emptyset-5 \mathrm{~mm} ; 40 \mathrm{~mm}$ in length) to uniformize incoming water flow (B) and prior flowing into the six parallel swimming lanes $(180 \times 30 \times 50 \mathrm{~mm} ; \mathrm{L} \times \mathrm{W} \times \mathrm{H})$ (C). Two mesh bands are installed on the extremities of each lane to avoid larvae from entering into the diffusers (B) and from being washed out from the chamber (D) at the water exit extremity (E).

Larvae were randomly selected from the holding tank and transferred to a swimming lane. Each larva was tested individually and allowed to acclimate for $5 \mathrm{~min}$ at a flow speed of $1 \mathrm{~cm} \mathrm{~s}^{-1}$. Individuals with stress symptoms observed during the acclimation period were replaced by another larva. After the acclimation period, the current velocity was increased by approximately $1 \mathrm{~cm} \mathrm{~s}^{-1}$ every 2 min until the larvae were unable to swim against the current for $2 \mathrm{~min}$, as established for other Sparidae [33]. The maximum flow speed tested was $22 \mathrm{~cm} \mathrm{~s}^{-1}$.

$\mathrm{U}_{\text {crit }}$ was calculated with Equation (1) [45]:

$$
U_{c r i t}=U+\left(t \times t^{-1} \times U_{i}\right)
$$

where $U$ is the second-last velocity increment that a larva could maintain, $U_{i}$ is the velocity increment (i.e., $1 \mathrm{~cm} \mathrm{~s}^{-1}$ ), $\mathrm{t}$ is the time swam in the final velocity increment, and $\mathrm{t}_{\mathrm{i}}$ is the time interval for each speed velocity $(2 \mathrm{~min})$. Larvae were not fed during the swimming experiments to avoid any effect on swimming performance. The average water temperature during the experiments was $19.5 \pm 1.4^{\circ} \mathrm{C}($ mean $\pm \mathrm{SD})$.

\subsubsection{Swimming Endurance}

Swimming endurance trials determine the time that larvae swim at a constant speed until exhaustion $[33,46]$. The swimming chamber apparatus used to calculate critical swimming speed $\left(U_{\text {crit }}\right)$ was also used in this test. Swimming endurance was performed at ages 15 (pre-flexion), 25, 35, and 45 (post-flexion) DPH for eight larvae in each day $(n=32$; Table 1$)$. A single larva was randomly collected from the holding tank and placed in a swimming lane to acclimatize for 5 min with water flowing at $1 \mathrm{~cm} \mathrm{~s}^{-1}$. Individuals showing symptoms of stress during the acclimation period were replaced by another larva. After the acclimatization period, water velocity was rapidly increased up to $~ 50 \%$ of the maximum $U_{\text {crit }}$ reached for each age [33] (Table 1), corresponding to a rough estimate of in situ swimming speeds [4]. Endurance trials were recorded with a KONIG SAS-IPCAM110B camera (NEDIS, 's Hertogenbosch, Netherlands) during the entire experiment to determine the fatigue time, 
i.e., the moment when a larva stops swimming and is trapped in the retaining mesh. The distance swam by each larva was calculated based on the duration of the swimming trial and water flow speed [33]. Larvae were not fed during endurance experiments to avoid the effect of feeding on swimming performance. The experiments were conducted with an average temperature for each age of $20.0 \pm 2.0^{\circ} \mathrm{C}($ mean $\pm \mathrm{SD})$.

\subsubsection{Locomotory Behavior}

The locomotory behavior of white seabream larvae was categorized along ontogeny with the Modal Action Patterns (MAPs) [47,48]. The MAPs categorizes swimming behavior into four patterns, categorized into two main movements: (i) locomotory movements (swimming-larva swims forward in the water column; pause-swimming - larva displays short-pulse movements in the water column); and (ii) undirected movements (pause - larva is motionless and stationary in the water column; sink-larva is motionless and sinks to the bottom).

A total of 90 larvae were tested along ontogeny, ten larvae at each one of the following moments: $15,20,25,30,35,40,45,50$, and 55 DPH (Table 1). The larvae were placed inside a 500-mL glass beaker with food supplied ad libitum, and each one of the four swimming behaviors described above was recorded for one minute.

\subsubsection{Physiological Condition}

The analysis of nucleic acids of fish larvae allows the inference of their physiological condition and nutritional condition [33,47-50] based on a series of indices that reflect variations in protein synthesis and, therefore, growth. The main premises of these types of derived nucleic acid indices is that the concentration of DNA in the somatic cells of animals remains relatively constant, while the concentration of RNA is related to the protein synthesis rates (recent growth) [51].

The concentration of nucleic acids (RNA, DNA) was quantified for each fish larva using a microplate fluorescent assay [52,53]. The extraction of nucleic acids from larvae involved the mechanical (sonication: 3 pulses at 50 A during 1 minute) and chemical homogenization of tissues (cold sarcosyl Tris-EDTA extraction buffer), the addition of Gel Red (GR) (a nucleic acid fluorochrome dye), and subsequent fluorescence-photometric measurements. Fluorescence was measured on a microplate reader (Biotek Synergy HT model SIAFRTD - BioTek®Instruments, Inc., Vermont, USA) with an excitation wavelength of $365 \mathrm{~nm}$ and an emission wavelength of $590 \mathrm{~nm}$. Following the first scan to determine total fluorescence of RNA and DNA, a ribonuclease A (Type-II A) solution was added to each well, and the concentration of DNA was calculated directly from the standard curve. The RNA fluorescence was calculated subtracting the DNA fluorescence (second scan) from total fluorescence (first scan). Concentrations were determined by running standard curves of DNA-GR and RNA-GR every day with known concentrations of $\lambda$-phagus DNA $\left(0.25 \mu \mathrm{g} \mu \mathrm{L}^{-1}\right)$ and 16S-23S E. coli RNA $\left(4 \mu \mathrm{g} \mu \mathrm{L}^{-1}\right)$ (Roche). The average ratio of DNA and RNA slopes (average $\pm \mathrm{SD}$ ) was $3.56 \pm 0.59$. The RNA/DNA ratios were standardized (sRD) using DNA and RNA slope ratios and the reference slope ratio of 2.4 [54].

Aliquots of the bicinchoninic acid protein assay were used for protein quantification [55]. The extraction procedure consisted of using a sarcosyl solution for the extraction of nucleic acids, with a copper sulfate:bicinchoninic acid (1:50) as a protein reagent. Protein concentration $\left(\mu \mathrm{g}\right.$ protein $\mathrm{mg}^{-1}$ dry weight) was quantified through a standard curve using bovine serum albumin P-0914 (SIGMA Merck KGaA, Darmstadt, German). The absorbance was measured at $562 \mathrm{~nm}$ after incubation at $37^{\circ} \mathrm{C}$ for $30 \mathrm{~min}$ on a microplate reader (Biotek Synergy HT model SIAFRTD).

The physiological condition of larvae was estimated with nucleic acid- and protein-derived indices: RNA ( $\mu \mathrm{g} \mathrm{mg}^{-1} \mathrm{DW}$ ), DNA ( $\mu \mathrm{g} \mathrm{mg} \mathrm{m}^{-1} \mathrm{DW}$ ), sRD (standardized RNA/DNA ratios), resRNA (residual-based index from RNA content), and proteins $\left(\mu \mathrm{g} \mathrm{larva}^{-1}\right)$. The residual-based index from RNA was used to remove the allometric size effect and derived from the residuals of a global regression of $\operatorname{Ln}(\mathrm{RNA}+1$ on $\ln (\mathrm{DW}))[35,36]$. The effect of size on these indices was tested with a linear model. 


\subsection{Data Analyses}

Since our dataset does not have a normal distribution, we used the non-parametric Spearman's rank correlation test to analyze the correlations between critical swimming speed and distance swam during endurance tests with a set of independent variables: (a) age (days post-hatching, DPH), (b) total length (TL, mm), (c) RNA, $\mu \mathrm{g} \mathrm{mg}^{-1} \mathrm{DW}$; (d) DNA, $\mu \mathrm{g} \mathrm{mg}^{-1} \mathrm{DW}$, (e) sRD; (f) resRNA; (g) $\mu$ g protein larva $^{-1}$. All statistical analyses were done in $\mathrm{R}$ (version 3.5.2). Data are presented as mean \pm standard deviation (SD).

\section{Results}

The swimming performance of white seabream larvae was tested with 175 individuals, 143 for critical swimming speed $\left(\mathrm{U}_{\text {crit }}\right)$ and 32 for endurance trials. There is a polynomial length-weight relationship for the larvae tested in these experiments (Figure 2A; Table S1). The total length increased linearly along ontogeny, varying between 2.2 and $27.5 \mathrm{~mm}$ at 15 and $55 \mathrm{DPH}$ in critical swimming speed experiments, and between 4.5 and $29.5 \mathrm{~mm}$ at 15 and $45 \mathrm{DPH}$ in endurance experiments (Figure 2B; Table S1). The larvae used in the endurance experiments came from a batch produced in May 2016, when the water temperature was higher, and for that reason, larvae were generally bigger at a given moment along ontogeny than the larvae tested in the critical swimming experiments (Figure 2).
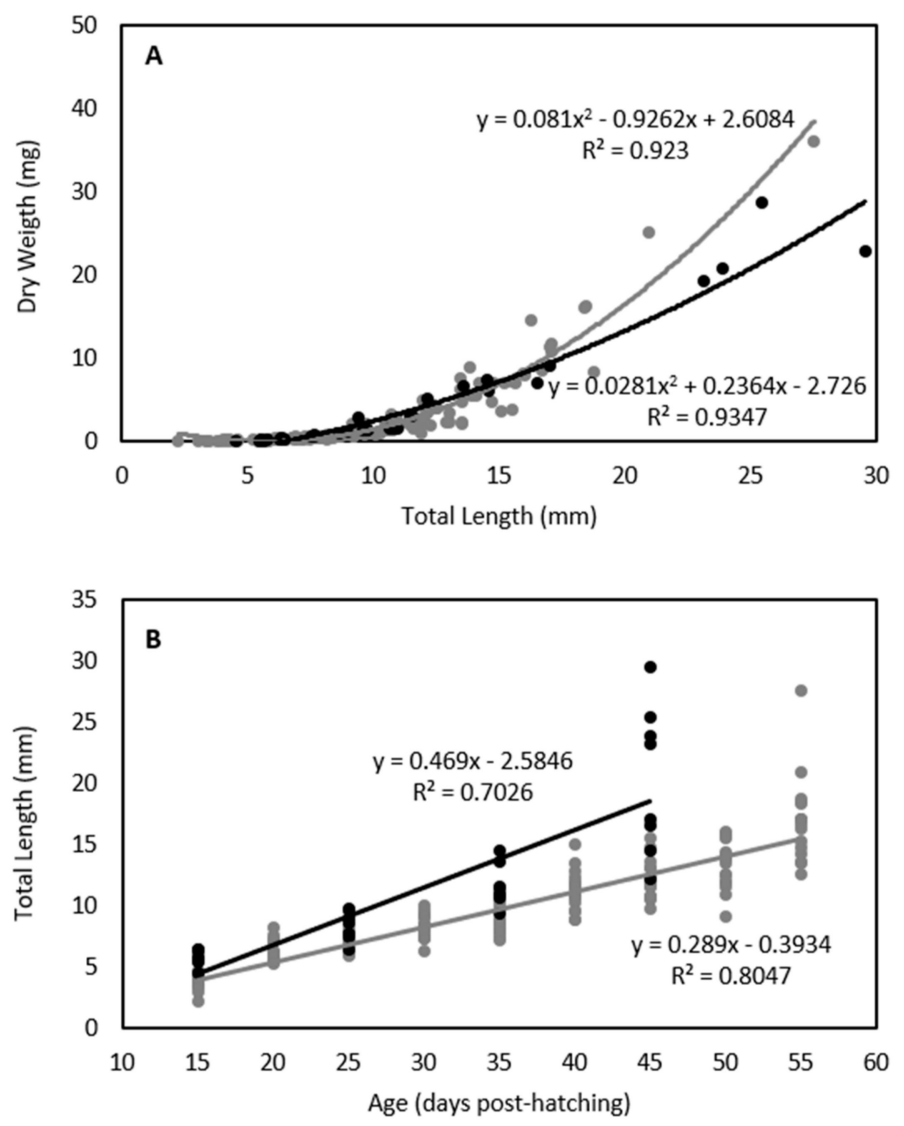

Figure 2. Relationship between total length $(\mathrm{mm})$ and dry weight $(\mathrm{mg})(\mathrm{n}=175)(\mathbf{A})$, and between age (days post-hatching) and total length $(\mathrm{mm})(\mathrm{n}=175)(\mathbf{B})$ for white seabream Diplodus sargus (Linnaeus, 1758) larvae tested for critical swimming speed (black) and endurance (grey) along ontogeny (15, 20, 25, $30,35,40,45,50$, and 55 days post-hatching).

The critical swimming speed increased throughout ontogeny from $1.9 \pm 0.7 \mathrm{~cm} \mathrm{~s}^{-1}$ at $15 \mathrm{DPH}$ up to $21.9 \pm 3.2 \mathrm{~cm} \mathrm{~s}^{-1}$ at $55 \mathrm{DPH}$, with a decrease at $30 \mathrm{DPH}$ (from $5.4 \pm 1.8 \mathrm{~cm} \mathrm{~s}^{-1}$ to $4.5 \pm 1.1 \mathrm{~cm} \mathrm{~s}^{-1}$ ) (Figure 3; Table S1). Critical swimming speed ranged from $1.1 \mathrm{~cm} \mathrm{~s}^{-1}$ at $15 \mathrm{DPH}$ and $23.0 \mathrm{~cm} \mathrm{~s}^{-1}$ 
at 50 and $55 \mathrm{DPH}$, which corresponds to 2.0 to 25.1 body lengths $\mathrm{s}^{-1}$, respectively. Spearman's rank correlations showed significant correlations between critical swimming speed and age $(\rho=0.85$, $p$-value $<0.001)$ and total length $(\rho=0.83, p$-value $<0.001)$ (Figure 3, Table 2$)$.

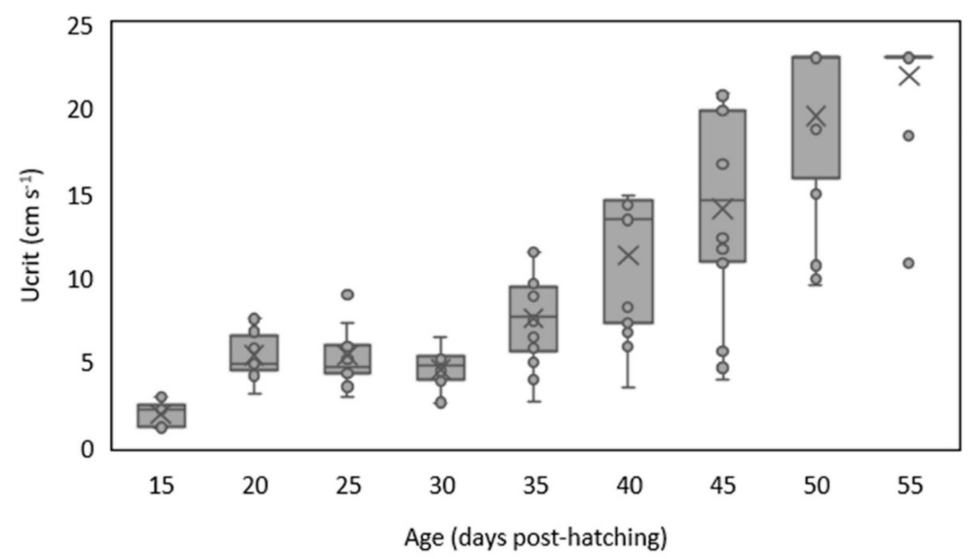

Figure 3. Variation of critical swimming speed $\left(\mathrm{U}_{\text {crit }} ; \mathrm{cm} \mathrm{s}^{-1}\right)$ for white seabream Diplodus sargus (Linnaeus, 1758) larvae along ontogeny $(15,20,25,30,35,40,45$, 50, and 55 days post-hatching). The lines inside the boxes represent the median, $\times$ represents the mean, the lower and upper box limits represent the $25^{\text {th }}$ and the $75^{\text {th }}$ percentiles, whiskers represent the standard deviation, while dots represent the outliers.

Table 2. Spearman's rank correlations ( $\rho$ ) between white seabream Diplodus sargus (Linnaeus, 1758) larvae's critical swimming speed (Ucrit) (A) and swimming endurance (B) with age (DPH—days post-hatching), total length (TL, mm), dry weight (DW, mg), nucleic acid concentrations (RNA, $\mu \mathrm{g}$ RNA $\mathrm{mg}^{-1}$ DW; DNA, $\mu$ g DNA mg. ${ }^{-1} \mathrm{DW}$; sRD, standardized RNA/DNA ratio; and resRNA, residuals of RNA), and proteins concentrations ( $\mu$ g protein larva ${ }^{-1}$ ). $p$-values were corrected using the Bonferroni corrections.

\begin{tabular}{cccc}
\hline Experiment & Correlation with & $\boldsymbol{\rho}$ & $\boldsymbol{p}$-value \\
\hline \multirow{4}{*}{$\mathbf{U}_{\text {crit }}$} & DPH & $\mathbf{0 . 8 5}$ & $<0.001$ \\
& TL & $\mathbf{0 . 8 3}$ & $<0.001$ \\
& RNA & -0.61 & $<0.001$ \\
& DNA & -0.58 & $<0.001$ \\
sRD & -0.37 & $<0.001$ \\
& resRNA & -0.16 & 0.061 \\
& Proteins & -0.55 & $<0.001$ \\
\hline \multirow{4}{*}{ Endurance } & DPH & $\mathbf{0 . 9 3}$ & $<0.001$ \\
& TL & $\mathbf{0 . 8 8}$ & $<0.001$ \\
& RNA & -0.56 & 0.001 \\
& DNA & -0.38 & 0.033 \\
& sRD & -0.16 & 0.388 \\
& resRNA & -0.08 & 0.668 \\
& Proteins & $-\mathbf{0 . 8 9}$ & $<0.001$ \\
\hline
\end{tabular}

The distance swam by larvae in the endurance tests also increased along ontogeny, showing a positive significant correlation with fish larvae age $(\rho=0.93, p$-value $<0.001)$ and total length $(\rho=0.88$, $p$-value $<0.001$ ) (Figure 3, Table 2). The average distance swam varied between $0.1 \pm 0.1 \mathrm{~km}$ at $15 \mathrm{DPH}$ (minimum distance at $15 \mathrm{DPH}-0.01 \mathrm{~km}$ ) and $54.1 \pm 22.1 \mathrm{~km}$ at $45 \mathrm{DPH}$ (maximum distance at 45 $\mathrm{DPH}-86.5 \mathrm{~km}$ ) (Figure 4A, Table S1). The biggest increment in larva swimming endurance occurred between ages 35 and $45 \mathrm{DPH}$, when average swimming distance increased 10.8 times, from $5.0 \pm 6.0 \mathrm{~km}$ to $54.1 \pm 22.1 \mathrm{~km}$ (Figure $4 \mathrm{~A}$, Table S1). The time larvae swam varied between $1.3 \pm 0.9 \mathrm{~h}$ at $15 \mathrm{DPH}$ and $150.1 \pm 61.3 \mathrm{~h}$ at $45 \mathrm{DPH}$, and ranged from $0.3 \mathrm{~h}(15 \mathrm{DPH})$ to $240.2 \mathrm{~h}(45 \mathrm{DPH})$ (Figure $4 \mathrm{~B})$. 

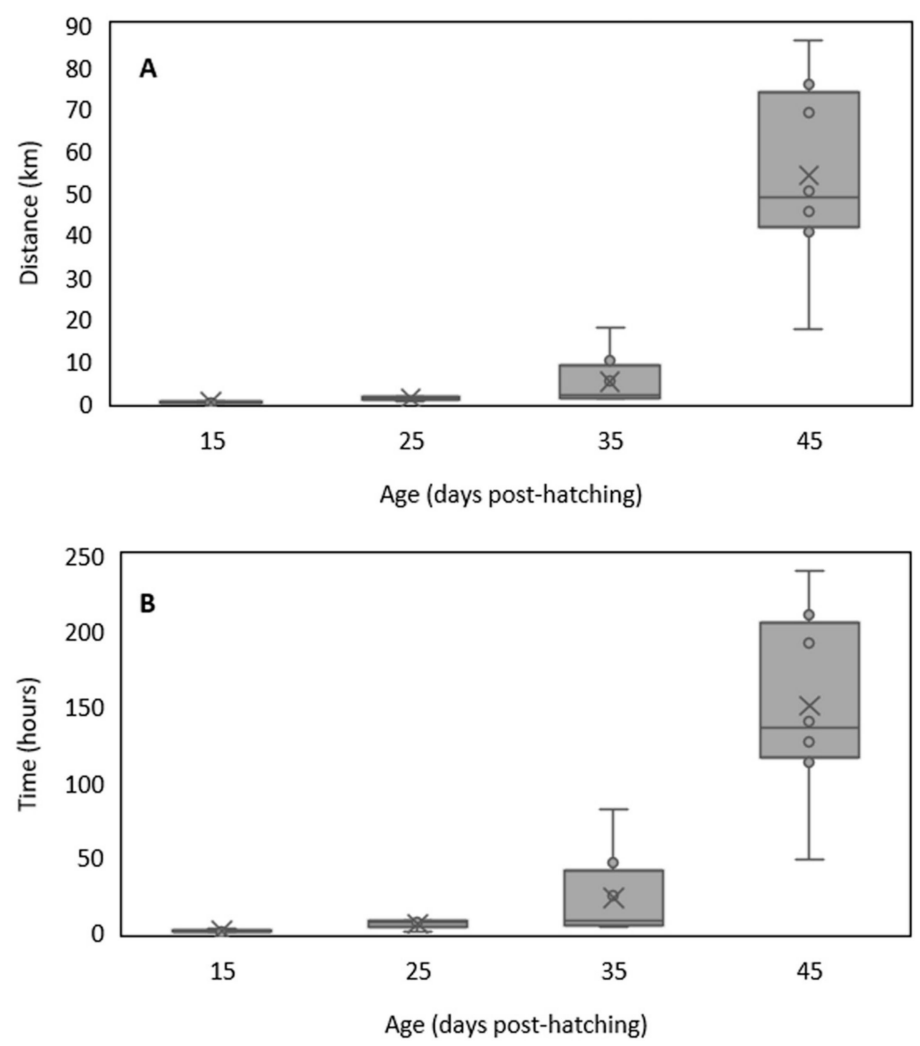

Figure 4. Distance (km) (A) and time (hours) (B) swam by white seabream Diplodus sargus (Linnaeus, 1758) larvae during swimming endurance experiments at $15,25,35$, and 45 days post-hatching. The lines inside the boxes represent the median, $\times$ represents the mean, the lower and upper box limits represent the $25^{\text {th }}$ and the $75^{\text {th }}$ percentiles, whiskers represent the standard deviation, while dots represent the outliers.

The mean concentration of nucleic acids (RNA, DNA) and standardized RNA/DNA ratio (sRD) of white seabream larvae tended to decrease with age (Table S1 in Supplementary Materials) and with swimming performance (critical swimming speed and swimming endurance), but the opposite trend was observed for the resRNA index and protein concentration (Figure 5). However, the condition indices showed weak negative correlations with critical swimming speed and swimming endurance (Figure 5, Table 2). The exception was found for protein content that showed a strong negative correlation with swimming endurance $(\rho=-0.89, p$-value $<0.001)$ (Table 2$)$.

The Modal Action Patterns (MAPs) showed that the swimming pattern tended to increase until $30 \mathrm{DPH}$, where the maximum time spent swimming (60 s) was reached, and then decreased until 55 DPH. Pause-swimming decreased until 30 DPH and then increased until 55 DPH (Figure 6). 

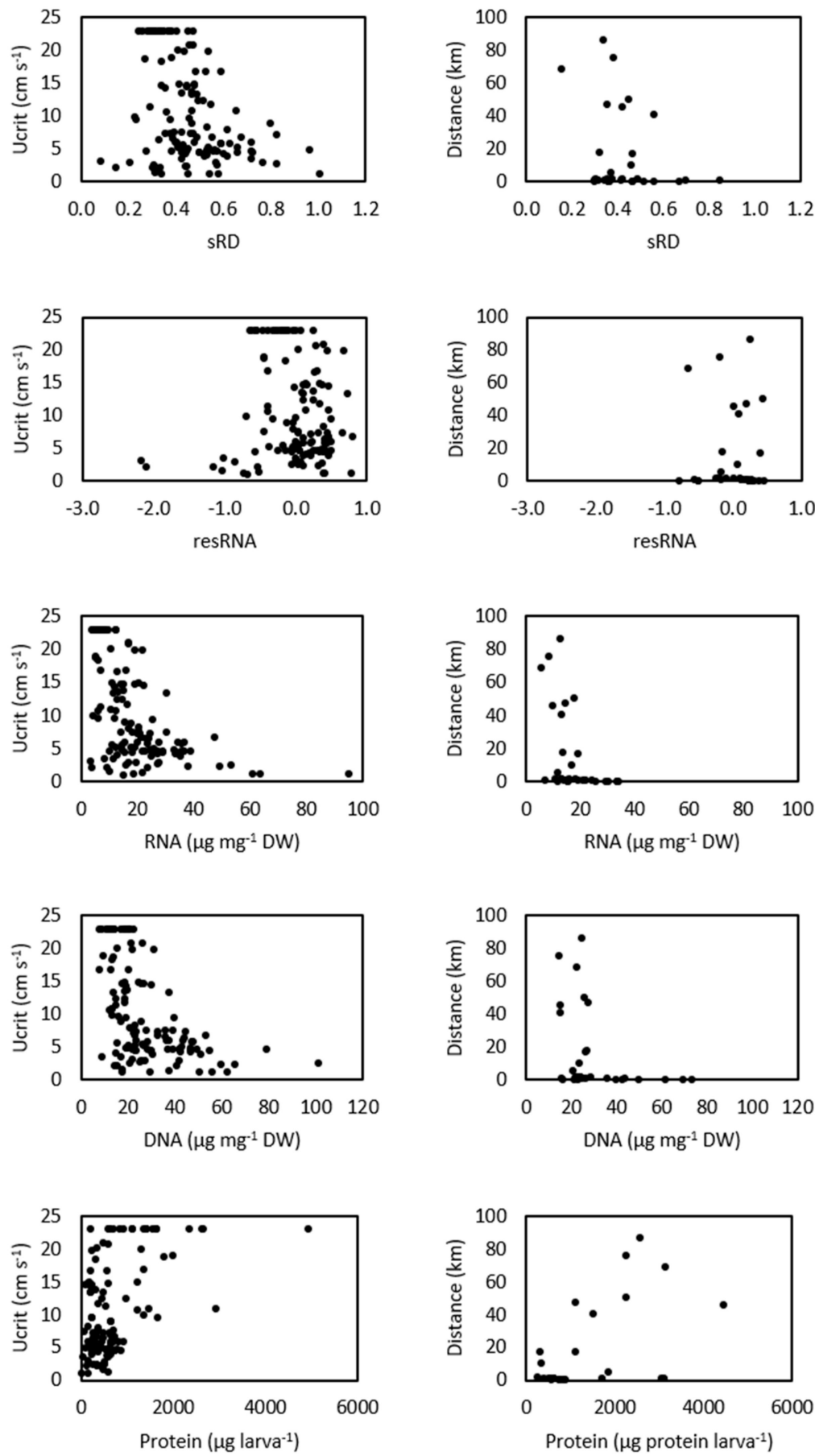

Figure 5. Relation between critical swimming speed $\left(\mathrm{U}_{\text {crit }}, \mathrm{cm} \mathrm{s}^{-1}\right)$ (left panels) and swimming endurance distance $(\mathrm{km})$ (right panels) with condition indices (RNA, $\mu \mathrm{g}$ RNA mg ${ }^{-1} \mathrm{DW}$; DNA, $\mu \mathrm{g}$ DNA $\mathrm{mg}^{-1} \mathrm{DW}$; sRD, standardized RNA:DNA ratio; resRNA, residuals of RNA; concentration of proteins, $\mu \mathrm{g}$ protein larva ${ }^{-1}$ ) for white seabream Diplodus sargus (Linnaeus, 1758) larvae tested along ontogeny $\left(15,20,25,30,35,40,45,50\right.$, and 55 days post-hatching (DPH) for $U_{\text {crit }}$ experiments, at 15,25 , 35 , and $45 \mathrm{DPH}$ for endurance experiments). An increase in sRD and resRNA indices corresponds to better nutritional condition. 


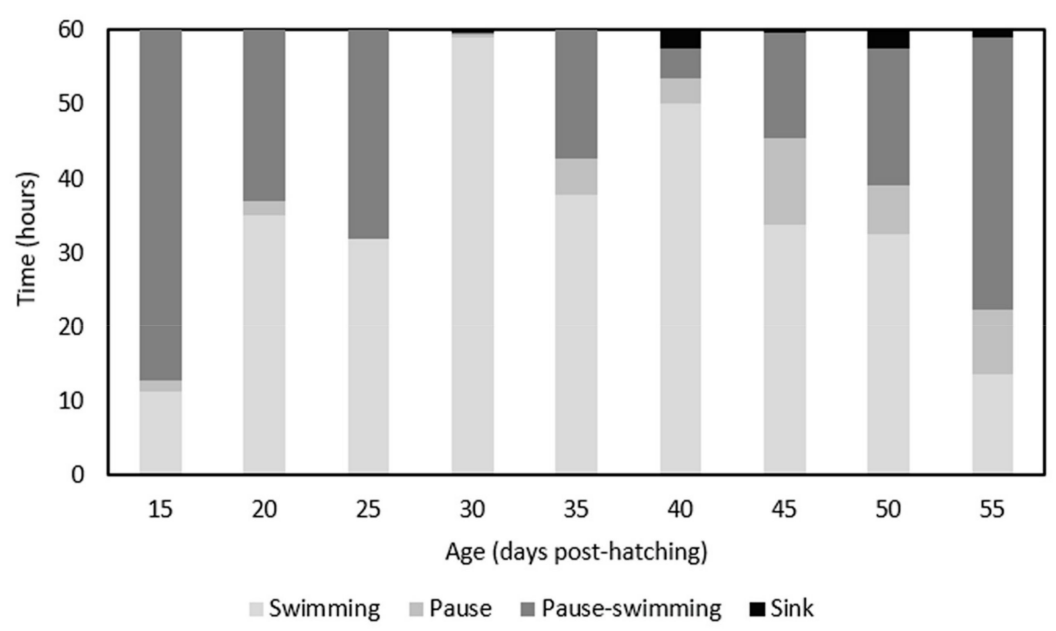

Figure 6. Mean time that white seabream Diplodus sargus (Linnaeus, 1758) larvae spent doing each Modal Action Pattern behavior (swimming, pause-swimming, pause, and sink) along ontogeny (DPH-days post-hatching).

\section{Discussion}

Our study reinforced the first premises of the Sense Acuity And Behavioral (SAAB) hypothesis [2], specifically the one mentioning that temperate pelagic fish larvae hatching from pelagic eggs may swim fast enough and are strong enough to control their dispersion in normal oceanographic conditions to allow them to ingress into coastal nursery areas or to prevent advection from them. The most spectacular result of this study was finding that unfed white seabream larvae can swim up to $86.5 \mathrm{~km}$ over $240.2 \mathrm{~h}$ (i.e., ten straight days) between 45 and $55 \mathrm{DPH}$. This fact, in addition to data already published, allow us to confirm that the notion that post-flexion fish larvae are, per definition, planktonic-wonderer organisms is incorrect. In the following sections, we will evaluate the implications of fish larvae swimming performance and physiological condition in dispersion and recruitment, as well as the putative effect of climate change.

\subsection{Swimming Performance of Temperate Fish Larvae}

Critical swimming speed and swimming endurance tests provide information on how fish larvae would be able to compensate for the advection caused by coastal currents and control, or not, their dispersion in coastal areas $[14,20,21,30,46,56]$ if they can detect coastal nursery habitats [2]. Critical swimming speed makes it possible to understand whether larvae can overcome strong currents, for short periods, that could disperse them away from their route, deter them from maintaining a stationary position, or from entering into water currents that would facilitate their retention or transport into nursery or recruitment habitats [44]. On the other hand, swimming endurance reveals the extraordinary ability of larvae to maintain directional swimming for long periods when nursery habitat cues, solar and stellar cues, or geomagnetic fields could be detected from far $[1,4,15,33,56]$.

Regarding pre-settlement temperate fish larvae, their swimming performances show their limited ability to control dispersion in coastal areas [4,47], as observed for pre-flexion white seabream larvae $\left(\mathrm{U}_{\text {crit }}=1.9 \pm 0.7 \mathrm{~cm} \mathrm{~s}^{-1}\right.$, swimming endurance $=0.1 \pm 0.1 \mathrm{~km}$ at $\left.15 \mathrm{DPH}\right)$ and other species (e.g., $\mathrm{U}_{\text {crit }}<$ $1.5 \mathrm{~cm} \mathrm{~s}^{-1}$ for the European pilchard Sardina pilchardus (Walbaum 1792) [47]; $\mathrm{U}_{\text {crit }}=1.8 \mathrm{~cm} \mathrm{~s}^{-1}$ for rockfish Sebastes spp. (Cuvier 1829) [20]). However, temperate fish larvae become good swimmers at later development stages, owing to the development of musculature and morphological structures associated with increased swimming capabilities [4]. Therefore, the critical swimming speed of temperate fish larvae tends to increase steadily along the ontogeny, while swimming endurance only increases later [56] owing to physiological changes [21], like the availability of energy reserves, increased growth [57], development of musculature [4] and fins [15]. This was also observed for the 
white seabream larvae, since the average swimming endurance increased abruptly from $5.0 \pm 6.0 \mathrm{~km}$ at $35 \mathrm{DPH}$ to $54.1 \pm 22.1 \mathrm{~km}$ at $45 \mathrm{DPH}$.

Flexion and post-flexion temperate fish larvae can be deterred from reaching nursery areas under unfavorable oceanographic conditions. However, under normal oceanographic conditions (e.g., $4-10 \mathrm{~cm} \mathrm{~s}^{-1}$ in the Portuguese coast; [58,59]), their swimming capabilities can place them en route to their desired destination. For example, the critical swimming speed of post-flexion temperate fish larvae (e.g., $0.6-9.2 \mathrm{~cm} \mathrm{~s}^{-1}$ for Atlantic herring Clupea harengus (Linnaeus 1758), $1.6-9.5 \mathrm{~cm} \mathrm{~s}^{-1}$ for sardine, 6.5-18.7 $\mathrm{cm} \mathrm{s}^{-1}$ for sand-smelt Atherina presbyter (Cuvier 1829), 1.1-20.5 s ${ }^{-1}$ for red drum Sciaenops ocellatus (Linnaeus 1766), and $2.5-23.0 \mathrm{bl} \mathrm{s}^{-1}$ for white seabream) $([27,44,47,60]$, as well as this study) may surpass the threshold set by prevailing oceanic currents [58,59]. The stamina of flexion and post-flexion temperate fish larvae is also surprising, because swimming endurance may exceed several dozen kilometers for many of the species studied-22.4 km for Japanese meagre Argyrosomus japonicus (Temminck and Schlegel 1844), $23.9 \mathrm{~km}$ for gilt-head seabream Sparus aurata (Linnaeus 1758), $32.4 \mathrm{~km}$ for Cape white seabream Diplodus capensis (Smith 1844), and $64.8 \mathrm{~km}$ for salema Salpa salpa (Linnaeus 1758)) $[33,46,56]$. In the specific case of the white seabream larvae, the maximum $(86.5 \mathrm{~km}$ during $240.2 \mathrm{~h}$ ) and average swimming endurance distances $\left(54.1 \pm 22.1 \mathrm{~km}\right.$ at a speed of $\left.10.0 \mathrm{~cm} \mathrm{~s}^{-1}\right)$ swam at 45-55 DPH were greater than the maximum recorded for any other Sparidae larvae (see Table 3). It is important to recall that larvae were not fed and did not rest during swimming endurance trials, so it is reasonable to extrapolate that larvae could have swum longer distances under more suitable conditions [57].

Table 3. Summary of reports on swimming performance (critical swimming speed-Ucrit;swimming endurance- $-\mathrm{km}$ ) of larvae of several temperate fish species. The size range of larvae tested is also shown.

\begin{tabular}{|c|c|c|c|c|c|c|c|}
\hline Order & Family & Species & $\begin{array}{l}\text { Size } \\
(\mathrm{mm})\end{array}$ & $\begin{array}{c}\mathrm{U}_{\text {crit }} \\
\left(\mathrm{cm} \mathrm{s}^{-1}\right)\end{array}$ & $\begin{array}{c}U_{\text {crit }} \\
\left(b l s^{-1}\right)\end{array}$ & $\begin{array}{c}\text { Endurance } \\
(\mathbf{k m})\end{array}$ & Reference \\
\hline Atheriniformes & Atheriniidae & Atherina presbyter & $6.6-21.0$ & $3.6-18.7$ & $5.2-17.6$ & - & [27] \\
\hline \multirow[t]{2}{*}{ Clupeiformes } & Clupeidae & Sardina pilchardus & $7.9-23.4$ & $1.6-9.5$ & $1.8-6.9$ & - & [47] \\
\hline & & Clupea harengus & $8.0-22.0$ & $0.0-9.2$ & $0.0-4.8$ & - & [60] \\
\hline Gadiformes & Gadidae & Gadus morhua & - & $1.2-9.7$ & $2.2-6.9$ & - & [61] \\
\hline Gobiesociformes & Gobiesocidae & Lepadogaster lepadogaster & $5.1-10.9$ & $1.0-9.4$ & $1.5-9.6$ & - & [62] \\
\hline \multirow{16}{*}{ Perciformes } & Carangidae & Carangidae sp. & - & $19.4 \pm 2.9$ & - & - & [31] \\
\hline & Percichthyidae & Macquaria novemaculeata & $4.0-10.4$ & $0-1.5$ & - & $0-12.5$ & [56] \\
\hline & Pomacentridae & Chromis chromis & $8.3-12.4$ & $19.0-35.6$ & $17.0-30.4$ & - & [30] \\
\hline & Sciaenidae & Argyrosomus japonicus & $3.0-14.0$ & $4.0-16.6$ & - & $0-22.4$ & [56] \\
\hline & & Scianops ocellatus & $3.0-19.1$ & $1.1-20.5$ & $3.1-20.4$ & - & [44] \\
\hline & Sparidae & Acanthopagrus australis & $4.9-11.1$ & $2.0-27.0$ & - & - & [56] \\
\hline & & Diplodus capensis & $8.9-16.0$ & $2.8-35.2$ & $\max 26.1$ & $0.2-32.4$ & [46] \\
\hline & & Diplodus sargus & - & $10.8 \pm 2.8$ & - & - & [31] \\
\hline & & & $1.3-29.5$ & $1.1-23.0$ & $2.0-27.2$ & $0.0-86.5$ & this study \\
\hline & & Oblada melanura & - & $21.3 \pm 3.1$ & - & - & [31] \\
\hline & & Pagellus acarne & - & $21.3 \pm 5.5$ & - & - & [31] \\
\hline & & Pagrus auratus & $2.2-10.4$ & $2.0-27.3$ & - & $4.0-9.9$ & [56] \\
\hline & & Sarpa salpa & $12.1-21.3$ & $4.8-33.4$ & $\max 15.7$ & $0.1-64.8$ & [46] \\
\hline & & Sparus aurata & $6.2-14.1$ & $3.0-19.3$ & $4.5-20.9$ & $10.2-23.9$ & [33] \\
\hline & & Spicara smaris & $9.0-13.9$ & $7.2-26.6$ & $5.5-22.4$ & - & [30] \\
\hline & & Spondyliosoma cantharus & $11.7-17.3$ & $12.0-26.6$ & $9.3-17.5$ & - & [30] \\
\hline \multirow[t]{2}{*}{ Pleuronectiformes } & Pleuronectidae & Pleuronectes platessa & $7.0-13.0$ & $1.0-3.9$ & $1.3-3.5$ & - & [29] \\
\hline & Soleidae & Solea senegalensis & $3.5-7.5$ & $0.4-5.0$ & $0.2-11.9$ & - & [19] \\
\hline
\end{tabular}

Biophysical models addressing the influence of larval behavior on dispersal (i.e., the ability to follow cues thanks to their horizontal and vertical movements) provide additional evidence on the extraordinary capacities of temperate fish larvae to control their dispersion in coastal areas $[2,10,11,30]$. Such models suggest that temperate fish larvae are active swimmers only requiring to make use of 
modest swimming speeds $\left(1-10 \mathrm{~cm} \mathrm{~s}^{-1}\right)$ to control their transport and distribution in coastal areas and to avoid offshore advection $[2,30]$.

\subsection{Swimming Performance and Larval Condition}

The total length of white seabream larvae used in the endurance experiments was higher than those used in the critical swimming experiments. This could have been due to different rearing conditions, as temperature, and to changes in the survival rate of slow growers between experiments. In the wild, most fish larvae face high mortality rates until settlement, either to predation [47] or competition [63]. Despite the effect of size on swimming performance, it was expected that other factors influenced swimming performance, such as larval condition [57]. However, age (DPH) and size (TL) were the best predictors of swimming performance (critical swimming speed and swimming endurance) for white seabream larvae. In the north-western Mediterranean Sea, several Sparidae larvae, including white seabream larvae, also showed significant relationships between critical swimming speed and body length [31]. However, other studies have found that body length was not the main factor responsible for critical swimming speed variability $[30,33]$.

Nucleic acid-derived indices (RNA, DNA, sRD) showed a tendency to decrease with larval development (size and age), and consequently with swimming performance ( $\mathrm{U}_{\text {crit }}$ and endurance). This is a common phenomenon $[19,33,47]$ since growth depends on the increase in cell size (hypertrophy), which reduces the concentration of nucleic acids in the amount of tissue [64]. Therefore, we used the RNA residual-based index and protein content to circumvent the effect of growth [49]. These two indices increased along ontogeny, as described for other species (e.g., Senegalese sole Solea senegalensis Kaup, 1858) [29]. The increase of protein content is associated with an increase of body mass and growth due to changes in the rates of protein synthesis and/or degradation, or to changes in protein retention [65]. Most of the condition indices tested in the present study were moderate or less correlated with swimming performance, as observed in other studies $[19,33,47,51,60]$. This might have occurred because most larvae were tested under optimal feeding conditions. Nonetheless, the protein content of white seabream larvae had a significant negative correlation with swimming endurance along the ontogeny. Likely this owes to the fact that white seabream larvae were not fed during swimming endurance trial, swimming until exhaustion and thus consuming their protein reserves.

\subsection{Climate Change and the Swimming Performance of Temperate Fish Larvae}

Water temperature has a direct impact on the metabolism, growth, and swimming performance of fish larvae [66,67]. Increased water temperature accelerates growth and improves muscle contractibility, as well as swimming performance [68]. Therefore, in a context of global climate change, temperate fish larvae hatching from pelagic eggs, such as the white seabream larvae, would theoretically benefit from increased sea surface temperature throughout several coastal regions in the world [69] because of improved swimming performance and reduced pelagic larval duration [70]. However, this would also imply an increase in energetic expenditure, leading to more time being spent on foraging [66,70]. In fact, after the flexion of the notochord, white seabream larvae spend more time in pause-swimming, which is associated with a saltatory foraging strategy to increase feeding efficiency [47]. Therefore, fish larvae may adapt their foraging strategies to their metabolic needs, which vary along with their development or with environmental changes. Thus, this crucial metabolic regulation might have negative impacts on fish populations if larvae are unable to balance the energy spend on thermal regulation and on all other activities that could promote their survival and growth [66]. The cascading effect of intrinsic factors responsible for the variability in larval survival interacts with the effects of currents on dispersal patterns [70], making it difficult to predict the effects of increased water temperature on larval swimming performance in the natural environment. 


\section{Conclusions}

The swimming performance of white seabream larvae shows that flexion and post-flexion larvae can swim faster than many coastal currents. White seabream larvae start to control their swimming at $20 \mathrm{DPH}$, which may allow them to swim along an increased gradient of coastal nursery cues to reach them and then to remain in those nursery areas, which further supports the first premise of the SAAB hypothesis. Age and size were the best predictors of critical swimming speed and swimming endurance for white seabream larvae. The protein content was the only condition index explaining the variability in swimming performance along ontogeny, especially in swimming endurance. Our results provide fundamental data for parameterizing individual-based biophysical models to understand population dynamics and connectivity along with coastal ecosystems, which will ultimately improve the management and conservation of fish stocks. The swimming capabilities of temperate fish larvae is one of the multiple factors affecting recruitment success; however, the influence of warming oceans on swimming abilities and its interaction with thermal regulation and time spent foraging to balance increase energy expenditure must be evaluated in future research efforts.

Supplementary Materials: The following are available online at http://www.mdpi.com/1424-2818/11/10/185/s1, Table S1: Mean and standard deviation values of critical swimming speed $\left(\mathrm{U}_{\text {crit }}\right)$, distance swam in the endurance experiment, total length (TL), dry weight (DW), nucleic acid concentrations (RNA, DNA), sRD (standardized RNA:DNA ratio), resRNA (RNA residuals), and protein concentration (Proteins) for white seabream Diplodus sargus (Linnaeus, 1758) larvae at different ages (DPH - days post-hatching).

Author Contributions: Conceptualization, V.B. and M.A.T; Investigation, V.B.; Methodology, V.B.; Resources, L.R. and P.P.-F.; Supervision, F.L., E.W. and M.A.T; Writing-original draft, V.B., P.M., J.C., F.L. and M.A.T; Writing-review \& editing, V.B., P.M., J.C., S.C., L.R. and P.P.-F., F.L., E.W. and M.A.T.

Funding: V.B. (SFRH/BD/104209/2014) have Ph.D. scholarship funded by Foundation for Science and Technology (FCT). F. L. is funded by national funds by FCT, under the Transitional Norm (DL57/2016/CP[1361]/CT[CT0008).This study received Portuguese national funds from FCT-Foundation for Science and Technology through project UID/Multi/04326/2019, and CLIMFISH project-A framework for assess vulnerability of coastal fisheries to climate change in Portuguese coast founded by Portugal 2020, n2/SAICT/2017-SAICT (Projetos de IC\&DT).

Acknowledgments: The authors would like to thank the colleagues from Estação Piloto de Piscicultura de Olhão (EPPO)/Aquaculture Research Station-Instituto Português do Mar e da Atmosfera (IPMA, Portugal), especially to Marisa Barata and Tetyana Urshulyak.

Conflicts of Interest: The authors declare no conflict of interest. The funders had no role in the design of the study; in the collection, analyses, or interpretation of data; in the writing of the manuscript, or in the decision to publish the results.

Ethics Statement: CCMAR facilities and their staff are certified to house and conduct experiments with live animals ("group-1" license by the Veterinary General Directorate, Ministry of Agriculture, Rural Development and Fisheries of Portugal) in accordance with the three "R" policy and national and European legislation.

\section{References}

1. Bradbury, I.R.; Snelgrove, P.V.R. Contrasting larval transport in demersal fish and benthic invertebrates: The roles of behaviour and advective processes in determining spatial pattern. Can. J. Fish. Aquat. Sci. 2001, 58, 811-823. [CrossRef]

2. Teodósio, M.A.; Paris, C.B.; Wolanski, E.; Morais, P. Biophysical processes leading to the ingress of temperate fish larvae into estuarine nursery areas: A review. Estuar. Coast. Shelf Sci. 2016, 183, 187-202. [CrossRef]

3. Montgomery, J.C.; Tolimieri, N.; Haine, O.S. Active habitat selection by pre-settlement reef fishes. Fish Fish. 2001, 2, 261-277. [CrossRef]

4. Leis, J.M. Are larvae of demersal fishes plankton or nekton? Adv. Mar. Biol. 2006, 51, 59-141. [CrossRef]

5. Houde, E.D. Emerging from Hjort's shadow. J. Northwest Atl. Fish Sci. 2008, 41, 53-70. [CrossRef]

6. Faillettaz, R.; Blandin, A.; Paris, C.B.; Koubbi, P.; Irisson, J.O. Suncompass orientation in Mediterranean fish larvae. PLoS ONE 2015, 10, e0135213. [CrossRef] [PubMed]

7. Mouritsen, H.; Atema, J.; Kingsford, M.J.; Gerlach, G. Sun compass orientation helps coral reef fish larvae return to their natal reef. PLoS ONE 2013, 8, e66039. [CrossRef] 
8. Atema, J.; Kingsford, M.J.; Gerlach, G. Larval reef fish could use odour for detection, retention and orientation to reefs. Mar. Ecol. Prog. Ser. 2002, 241, 151-160. [CrossRef]

9. Watt-Pringle, P.; Strydom, N.A. Habitat use by larval fishes in a temperate South African surf zone. Estuar. Coast. Shelf Sci. 2003, 58, 765-774. [CrossRef]

10. Faillettaz, R.; Paris, C.B.; Irisson, J.O. Larval fish swimming behavior alters dispersal patterns from marine protected areas in the North-Western Mediterranean Sea. Front. Mar. Sci. 2018, 5, 97. [CrossRef]

11. Lett, C.; Barriera, N.; Ourmièresb, Y.; Petita, C.; Labonnea, M.; Bourjeaa, J.; Darnaudea, A.M. Modeling larval dispersal for the gilthead seabream in the northwestern Mediterranean Sea. Mar. Environ. Res. 2019, 104781. [CrossRef] [PubMed]

12. Wright, K.J.; Higgs, D.M.; Belanger, A.J.; Leis, J.M. Auditory and olfactory abilities of pre-settlement larvae and post-settlement juveniles of a coral reef damselfish (Pisces: Pomacentridae). Mar. Biol. 2005, 147, 1425-1434. [CrossRef]

13. Wolanski, E.; Kingsford, M.J. Oceanographic and behavioural assumptions in models of the fate of coral and coral reef fish larvae. J. R. Soc. Interface 2014, 11, 20140209. [CrossRef] [PubMed]

14. Stobutzki, I.C.; Bellwood, D.R. Sustained swimming abilities of the late pelagic stages of coral reef fishes. Mar. Ecol. Prog. Ser. 1997, 149, 35-41. [CrossRef]

15. Atema, J.; Gerlach, G.; Paris, C.B. Sensory biology and navigation behavior of reef fish larvae. In Ecology of Fishes on Coral Reefs; Mora, C., Ed.; Cambridge University Press: Cambridge, UK, 2015; pp. 3-15.

16. Paris, C.; Cowen, R.K. Direct evidence of a biophysical retention mechanism for coral reef fish larvae. Limnol. Oceanogr. 2004, 49, 1964-1979. [CrossRef]

17. Jørgensen, C.; Opdal, A.F.; Fiksen, Ø. Can behavioural ecology unite hypotheses for fish recruitment? ICES J. Mar. Sci. 2014, 71, 909-917. [CrossRef]

18. Weins, J.A.; Stenseth, N.C.; van Horne, B.; Ins, R.A. Ecological mechanisms and landscape ecology. Oikos 1995, 66, 369-380. [CrossRef]

19. Faria, A.M.; Muha, T.; Morote, E.; Chícharo, M.A. Influence of starvation on the critical swimming behavior of the Senegalese sole (Solea senegalensis) and its relationship with RNA:DNA ratios during ontogeny. Sci. Mar. 2011, 75, 87-94. [CrossRef]

20. Kashef, N.S.; Sogard, S.M.; Fisher, R.; Largier, J.L. Ontogeny of critical swimming speeds for larval and pelagic juvenile rockfishes (Sebastes spp., family Scorpaenidae). Mar. Ecol. Prog. Ser. 2014, 500, 231-243. [CrossRef]

21. Fisher, R.; Bellwood, D.R.; Job, S.D. Development of swimming abilities in reef fish larvae. Mar. Ecol. Prog. Ser. 2000, 202, 163-173. [CrossRef]

22. Stobutzki, I.C.; Bellwood, D.R. An analysis of the sustained swimming abilities of pre- and post-settlement coral reef fishes. J. Exp. Mar. Bio. Ecol. 1994, 175, 275-286. [CrossRef]

23. Fisher, R.; Leis, J.M.; Clark, D.; Wilson, S.K. Critical swimming speeds of late-stage coral reef fish larvae: Variation within species, among species and between locations. Mar. Biol. 2005, 147, 1201-1212. [CrossRef]

24. Leis, J.M.; Wright, K.J.; Johnson, R.N. Behaviour that influences dispersal and connectivity in the small, young larvae of a reef fish. Mar. Biol. 2007, 153, 103-117. [CrossRef]

25. Leis, J.M.; Hay, A.C.; Howarth, G.J. Ontogeny of in situ behaviours relevant to dispersal and population connectivity in larvae of coral-reef fishes. Mar. Ecol. Prog. Ser. 2009, 379, 163-179. [CrossRef]

26. Koumoundouros, G.; Ashton, C.; Xenikoudakis, G.; Giopanou, I.; Georgakopoulou, E.; Stickland, N. Ontogenetic differentiation of swimming performance in gilthead seabream (Sparus aurata, Linnaeus 1758) during metamorphosis. J. Exp. Mar. Bio. Ecol. 2009, 370, 75-81. [CrossRef]

27. Faria, A.M.; Borges, R.; Gonçalves, E.J. Critical swimming speeds of wild-caught sand-smelt Atherina presbyter larvae. J. Fish. Biol. 2014, 85, 953-959. [CrossRef] [PubMed]

28. Peck, M.A.; Huebert, K.B.; Llopiz, J.K. Intrinsic and extrinsic factors driving match-mismatch dynamics during the early life history of marine fishes. Adv. Ecol. Res. 2012, 47, 177-302. [CrossRef]

29. Silva, L.; Moyano, M.; Illing, B.; Faria, A.M.; Garrido, S.; Peck, M.A. Ontogeny of swimming capacity in plaice (Pleuronectes platessa) larvae. Mar. Biol. 2015, 162, 753-761. [CrossRef]

30. Faillettaz, R.; Durand, E.; Paris, C.B.; Koubbi, P.; Irisson, J.-O. Swimming speeds of Mediterranean settlement-stage fish larvae nuance Hjort's aberrant drift hypothesis. Limnol. Oceanogr. 2018, 63, 509-523. [CrossRef] 
31. Rossi, A.; Levaray, M.; Paillon, C.; Durieux, E.D.H.; Pasqualini, V.; Agostini, S. Relationship between swimming capacities and morphological traits of fish larvae at settlement stage: A study of several coastal Mediterranean species. J. Fish Biol. 2019. [CrossRef]

32. Leis, J.M. Ontogeny of behaviour in larvae of marine demersal fishes. Ichthyol. Res. 2010, 57, 325-342. [CrossRef]

33. Faria, A.M.; Chícharo, M.A.; Gonçalves, E.J. Effects of starvation on swimming performance and body condition of pre-settlement Sparus aurata larvae. Aquat. Biol. 2011, 12, 281-289. [CrossRef]

34. Erzini, K.; Gonçalves, J.M.S.; Bentes, L.; Lino, P.J.; Ribeiro, J. Catch composition, catch rates and size selectivity of three long-line methods in the Algarve (southern Portugal). Bol. Inst. Esp. Oceanogr. 1999, 15, 313-323.

35. Veiga, P.; Ribeiro, J.; Gonçalves, J.M.S.; Erzini, K. Quantifying recreational shore angling catch and harvest in southern Portugal (north-east Atlantic Ocean): Implications for conservation and integrated fisheries management. J. Fish. Biol. 2010, 76, 2216-2237. [CrossRef]

36. Pajuelo, J.G.; Lorenzo, J.M. Growth and age estimation of Diplodus sargus cadenati (Sparidae) off the Canary Islands. Fish. Res. 2002, 59, 93-100. [CrossRef]

37. Ribeiro, J.; Bentes, L.; Coelho, R.; Goncalves, J.M.S.; Lino, P.G.; Monteiro, P.; Erzini, K. Seasonal, tidal and diurnal changes in fish assemblages in the Ria Formosa lagoon (Portugal). Estuar. Coast. Shelf Sci. 2006, 67, 461-474. [CrossRef]

38. Faria, A.; Morais, P.; Chícharo, M.A. Ichthyoplankton dynamics in the Guadiana estuary and adjacent coastal area, South-East Portugal. Estuar. Coast. Shelf Sci. 2006, 70, 85-97. [CrossRef]

39. Harmelin-Vivien, M.L.; Harmelin, J.G.; Leboulleux, V. Microhabitat requirements for settlement of juvenile sparid fishes on Mediterranean rocky shores. Hydrobiologia 1995, 301, 309-320. [CrossRef]

40. Di Franco, A.; Guidetti, P. Patterns of variability in early-life traits of fishes depend on spatial scale of analysis. Biol. Lett. 2011, 7, 454-456. [CrossRef]

41. Monteiro, C.C.; Lasserre, G.; Lam Hoi, T. Organisation spatiale des communautés ichtyologiques de la Lagune Ria Formosa (Portugal). Oceanol. Acta 1990, 13, 79-96.

42. Planes, S.; Jouvenel, J.-Y.; Biagi, F.; Francour, P.; Harmelin-Vivien, M.; Macpherson, E.; Tunesi, L.; Galzin, R. Spatio-temporal variability in growth of juvenile sparid fishes from the Mediterranean littoral. J. Mar. Biol. Assoc. UK 1999, 79, 137-143. [CrossRef]

43. Ortiz-Delgado, J.B.; Darias, M.J.; Cañavate, J.P.; Yúfera, M.; Sarasquete, C. Organogenesis of the digestive tract in the white seabream, Diplodus sargus. Histological and histochemical approaches. Histol. Histopathol. 2003, 18, 1155-1168. [CrossRef]

44. Faria, A.; Ojanguren, A.; Fuiman, L.; Gonçalves, E. Ontogeny of critical swimming speed of wild-caught and laboratory-reared larvae of red drum (Scieanops ocellatus). Mar. Ecol. Prog. Ser. 2009, 384, 221-230. [CrossRef]

45. Brett, J.R. The respiratory metabolism and swimming performance of young sockeye salmon. J. Fish. Res. Board. Can. 1964, 21, 1183-1226. [CrossRef]

46. Pattrick, P.; Strydom, N.A. Swimming abilities of wild-caught, late-stage larvae of Diplodus capensis and Sarpa salpa (Pisces: Sparidae) from temperate South Africa. Estuar. Coast. Shelf Sci. 2009, 85, 547-554. [CrossRef]

47. Silva, L.; Faria, A.M.; Teodósio, M.A.; Garrido, S. Ontogeny of swimming behaviour in sardine Sardina pilchardus larvae and effect of larval nutritional condition on critical speed. Mar. Ecol. Prog. Ser. 2014, 504, 287-300. [CrossRef]

48. Barlow, G.W. Ethological units of behavior. In The Central Nervous System and Fish Behavior; Ingle, D.J., Ed.; University of Chicago Press: Chicago, IL, USA, 1968; pp. 217-232.

49. Chícharo, M.A.; Chícharo, L.; Valdés, L.; López-Jamar, E.; Ré, P. Estimation of starvation and diel variation of the RNA/DNA ratios in field-caught Sardina pilchardus larvae off the north of Spain. Mar. Ecol. Prog. Ser. 1998, 164, 273-283. [CrossRef]

50. Buckley, L.; Caldarone, E.; Ong, T.L. RNA-DNA ratio and other nucleic acid-based indicators for growth and condition of marine fishes. Hydrobiologia 1999, 401, 265-277. [CrossRef]

51. Bulow, F.J. RNA-DNA ratios as indicators of recent growth rates of a fish. J. Fish. Res. Board Can. 1970, 27, 2343-2349. [CrossRef]

52. Wagner, M.M.; Durbin, E.G.; Buckley, L.J. RNA/DNA ratios as indicators of nutritional condition in the copepod Calanus finmarchicus. Mar. Ecol. Prog. Ser. 1998, 162, 173-181. [CrossRef] 
53. Caldarone, E.M.; Wagner, M.; St Onge-Burns, J.; Buckley, L.J. Protocol and guide for estimating nucleic acids in larval fish using a fluorescence microplate reader. In Northeast Fisheries Science Center Reference Document 01-11; Woods Hole: Falmouth, MA, USA, 2001; p. 22.

54. Caldarone, E.M.; Clemmesen, C.; Berdalet, E.; Miller, T.J.; Folkvord, A.; Holt, G.; Olivar, M.P.; Suthers, I.M. Intercalibration of four spectrofluorometric protocols for measuring RNA/DNA ratios in larval and juvenile fish. Limnol. Oceanogr. Methods 2006, 4, 153-163. [CrossRef]

55. Smith, P.K.; Krohn, R.I.; Hermanson, G.T.; Mallia, A.K.; Gartner, F.H.; Provenzano, M.D.; Fujimoto, E.K.; Goeke, N.M.; Olson, B.J.; Klenk, D.C. Measurement of protein using bicinchoninic acid. Anal. Biochem. 1985, 150, 76-85. [CrossRef]

56. Clark, D.L.; Leis, J.M.; Hay, A.C.; Trnski, T. Swimming ontogeny of larvae of four temperate marine fishes. Mar. Ecol. Prog. Ser. 2005, 292, 287-300. [CrossRef]

57. Leis, J.M.; McCormick, M.I. The biology, behaviour and ecology of the pelagic, larval stage of coral-reef fishes. In Coral Reef Fishes: New Insights into their Ecology; Sale, P.F., Ed.; Academic Press: San Diego, CA, USA, 2002; pp. 171-199.

58. Sánchez, R.F.; Mason, E.; Relvas, P.; da Silva, A.J.; Peliz, A. On the inner-shelf circulation in the northern Gulf of Cádiz, southern Portuguese shelf. Deep Sea Res. II 2006, 53, 1198-1218. [CrossRef]

59. Zuo, J.; Du, L.; Peliz, A.; Santos, A.M.P.; Yu, Y. The characteristics of near-surface velocity during the upwelling season on the northern Portugal shelf. J. Ocean Univ. China 2007, 6, 213-225. [CrossRef]

60. Moyano, M.; Illing, B.; Peschutter, P.; Huebert, K.B.; Peck, M.A. Thermal impacts on the growth, development and ontogeny of critical swimming speed in Atlantic herring larvae. Comp. Biochem. Physiol. A Mol. Integr. Physiol. 2016, 197, 23-34. [CrossRef]

61. Guan, L.; Snelgrove, P.V.R.; Gamperl, A.K. Ontogentic changes in the critical swimming speed of Gadus morhua (Atlantic cod) and Myoxocephalus scorpius (shorthorn sculpin) larvae and the role of temperature. J. Exp. Mar. Biol. Ecol. 2008, 360, 31-38. [CrossRef]

62. Faria, A.; Gonçalves, E. Ontogeny of swimming behaviour of two temperate clingfishes, Lepadogaster lepadogaster and Lepadogaster purpurea (Gobiesocidae). Mar. Ecol. Prog. Ser. 2010, 414, 237-248. [CrossRef]

63. Houde, E.D. Fish early life dynamics and recruitment variability. Am. Fish. Soc. Symp. 1987, 2, 17-29.

64. Olivar, M.P.; Diaz, M.V.; Chícharo, M.A. Tissue effect on RNA: DNA ratios of marine fish larvae. Sci. Mar. 2009, 73, 171-182. [CrossRef]

65. Houlihan, D.F.; Mathers, E.M.; Foster, A. Biochemical correlates of growth rate in fish. In Fish Ecophysiology; Rankin, J.C., Jensen, F.B., Eds.; Chapman and Hall: London, UK, 1993; pp. 45-71.

66. Houde, E.D. Comparative growth, mortality, and energetics of marine fish larvae: Temperature and implied latitudinal effects. Fish. Bull. 1989, 87, 471-495.

67. Green, B.S.; Fisher, R. Temperature influences swimming speed, growth and larval duration in coral reef fish larvae. J. Exp. Mar. Bio. Ecol. 2004, 299, 115-132. [CrossRef]

68. Fuiman, L.; Batty, R.S. What a drag it is getting cold: Partitioning the physical and physiological effects of temperature on fish swimming. J. Exp. Biol. 1997, 200, 1745-1755. [PubMed]

69. Intergovernmental Panel on Climate Change (IPCC). Climate change 2007: The physical science basis. In Contribution of Working Group I to the Fourth Assessment Report of the Intergovernmental Panel on Climate Change; Cambridge University Press: Cambridge, UK, 2007.

70. Munday, P.L.; Jones, G.P.; Pratchett, M.S.; Williams, A.J. Climate change and the future for coral reef fishes. Fish Fish. 2008, 9, 261-285. [CrossRef]

(C) 2019 by the authors. Licensee MDPI, Basel, Switzerland. This article is an open access article distributed under the terms and conditions of the Creative Commons Attribution (CC BY) license (http://creativecommons.org/licenses/by/4.0/). 